\title{
Insulin Delivery Rate in Response to Glucose and Arginine Infusion in Hyperthyroidism
}

\author{
T.Asano and M.Okumura \\ First Department of Internal Medicine, School of Medicine, Fukuoka University, Nanakuma, Fukuoka, Japan
}

\begin{abstract}
Summary. Insulin delivery rates were estimated from the peripheral serum insulin response to a single bolus injection of glucose or arginine in eight normal subjects and eight patients with hyperthyroidism. The mean rate constant for insulin disappearance was $0.2380 \pm 0.0052$ per min in the control subjects, which was not significantly different from that observed in the patients with hyperthyroidism $(0.2147 \pm 0.0111$ per $\mathrm{min})$. There were also no significant differences in the insulin response to glucose infusion $(1.7 \pm 0.3 \mathrm{U}$ during the first phase $(0-10 \mathrm{~min})$ and $5.6 \pm 1.6 \mathrm{U}$ during the second phase (11-60 min) in normal subjects compared with $1.2 \pm 0.5$ and $3.7 \pm 1.1 \mathrm{U}$ respectively in the hyperthyroid patients). The delivered insulin in response to glucose infusion was similar in the two groups. The $\mathrm{kg}$-value in the patients with hyperthyroidism was lower than that in the control subjects (1.24 \pm 0.11 versus $2.11 \pm 0.22 ; p<0.005$ ). In hyperthyroidism, the low $\mathrm{kg}$-value was not a result of the diminished insulin delivery to the general circulation. Insulin delivery showed a monophasic pattern following arginine infusion in both pa-
\end{abstract}

tients and control subjects. For the control subjects, the amount of insulin delivered was estimated to be $0.53 \pm 0.12 \mathrm{U}$ during the first $10 \mathrm{~min}$ and $0.37 \pm 0.14 \mathrm{U}$ during $11-30 \mathrm{~min}$. In hyperthyroidism, the amount of insulin delivered was significantly lower than in the control subjects $(0.21 \pm 0.06 \mathrm{U}$ during the first $10 \mathrm{~min}$ and $0.07 \pm 0.03 \mathrm{U}$ during $11-30 \mathrm{~min}$ ). In the control subjects, the plasma glucose level was raised transiently following arginine infusion, but in hyperthyroidism, there was no change in plasma glucose levels. In hyperthyroidism, therefore, glucose intolerance appears to be primarily related to an antagonism of the hepatic effect of insulin by thyroxine rather than an inhibitory effect of thyroxine on insulin secretion. However, since delivery rate represents the measurement of peripheral serum insulin concentrations, these results cannot exclude an abnormality of hepatic insulin metabolism in hyperthyroidism.

Key words: Insulin delivery rate, insulin secretion in hyperthyroidism, glucose, arginine, insulin disappearance rate.
Glucose tolerance and insulin secretion have been examined extensively in hyperthyroidism [1-4], and a reduced glucose tolerance has been found in patients with this condition $[2,3]$. However, intravenous glucose infusions in hyperthyroid men or dogs have produced conflicting results concerning plasma insulin secretion [2-5].

The mechanism of glucose intolerance is uncertain. It could be a consequence of a decreased capacity of insulin secretion or increased insulin catabolism [6]. In the present study, we have measured insulin delivery rates, calculated on the basis of fractional insulin disappearance rates following glucose infusion, in order to understand further B cell function in hyperthyroidism. Since the arginine-induced insulin response has been reported to be impaired in hyperthyroidism [7], the effect of arginine on the insulin delivery was also investigated.

\section{Subjects and Methods}

Eight patients with untreated hyperthyroidism had a mean age of 37 years and a mean ideal body weight of $91 \pm 3 \%$. The diagnosis of hyperthyroidism was established by clinical symptoms and the results of ${ }^{131}$ I uptake studies, T3-resin uptake, plasma thyroxine levels and basal metabolic rates (Table 1). Patients with clinical diabetes mellitus were excluded. Eight age-matched healthy men had a mean ideal body weight of $105 \pm 3 \%$ and were heavier than the hyperthyroid patients $(90 \pm 3 \% ; p<0.05)$. All subjects ate a diet containing more than $200 \mathrm{~g}$ carbohydrate daily for 3 days before each test. The tests were performed after an overnight fast.

An antecubital IV catheter was kept patent with $0.154 \mathrm{~mol} / 1$ saline and blood was sampled for measurement of insulin disappearance at $3,5,10,15,20,30,40,50$ and 60 min after the insulin infusion. Insulin (pork, Actrapid, Novo) was infused IV within $5 \mathrm{~s}$ at a dose of approximately $0.04 \mathrm{U} / \mathrm{kg}$ body weight in the hyperthyroid patients and $0.06 \mathrm{U} / \mathrm{kg}$ in the control subjects. Glucose $(20 \mathrm{~g} / \mathrm{dl})$ was given IV at a constant rate of $2.2 \mathrm{mg} \mathrm{kg}^{-1} \mathrm{~min}^{-1}$ (range; $2.0-2.7$ ) in the control subjects and $2.9 \mathrm{mg} \mathrm{kg}^{-1} \mathrm{~min}^{-1}$ (range; $2.4-3.5$ ) in the patients. The glu- 
Table 1. Clinical data in patients with hyperthyroidism

\begin{tabular}{|c|c|c|c|c|c|c|c|c|c|}
\hline $\begin{array}{l}\text { Patient } \\
\text { No. }\end{array}$ & Sex & $\begin{array}{l}\text { Age } \\
\text { (years) }\end{array}$ & $\begin{array}{l}\text { Body } \\
\text { weight } \\
(\mathrm{kg})\end{array}$ & $\begin{array}{l}\% \text { of ideal } \\
\text { body weight }\end{array}$ & $\begin{array}{l}\text { T3-resin } \\
\text { uptake } \\
(\%)\end{array}$ & $\begin{array}{l}\text { T4 } \\
(\mathrm{nmol} / \mathrm{l})\end{array}$ & $\begin{array}{l}\text { Cholesterol } \\
(\mathrm{mmol} / \mathrm{l})\end{array}$ & $\begin{array}{l}{ }^{131} \mathrm{I}- \\
\text { uptake } \\
(\% \text { at } 24 \mathrm{~h})\end{array}$ & $\begin{array}{l}\text { Basal } \\
\text { metabolic } \\
\text { rate }\end{array}$ \\
\hline 2 & $\mathrm{M}$ & 24 & 43 & 76 & 53 & 320 & 3.1 & 62 & +43 \\
\hline 3 & $\mathrm{~F}$ & 38 & 51 & 95 & 43 & 240 & 4.3 & 88 & +15 \\
\hline 4 & M & 43 & 52 & 84 & 50 & 410 & 2.4 & 68 & +59 \\
\hline 7 & $\mathrm{~F}$ & 28 & 46 & 89 & 48 & 300 & - & 92 & +58 \\
\hline 8 & $\mathrm{~F}$ & 52 & 45 & 87 & 49 & 320 & 3.1 & - & +61 \\
\hline \multicolumn{2}{|c|}{ Mean \pm SEM } & $37 \pm 3$ & $51 \pm 2$ & $90 \pm 3$ & & & & & \\
\hline \multicolumn{10}{|c|}{ Normal subjects $(n=8)$} \\
\hline \multicolumn{2}{|c|}{ Mean \pm SEM } & $34 \pm 6$ & $64 \pm 3$ & $105 \pm 3$ & $(25-35)$ & $(60-190)$ & $(3.4-5.9)$ & $(15-45)$ & $( \pm 15)$ \\
\hline
\end{tabular}

Figures in parentheses $=$ range

cose infusion was started $60 \mathrm{~min}$ before the administration of insulin and continued throughout the entire $60 \mathrm{~min}$ experiment. The glucose infusion maintained plasma glucose and insulin concentrations slightly higher than fasting levels. The glucose levels were $5.1 \pm 0.1$ and $5.2 \pm 0.2 \mathrm{mmol} / 1$ after $55 \mathrm{~min}$ infusion, $5.2 \pm 0.1$ and $5.0 \pm$ $0.3 \mathrm{mmol} / \mathrm{l}$ after $60 \mathrm{~min}$ infusion in the control subjects and patients, respectively. Insulin levels in the controls and the patients were $17 \pm$ 3.0 and $9.5 \pm 0.9 \mathrm{mU} / 1$ after $55 \mathrm{~min}$ infusion and $16 \pm 1.6$ and $9.3 \pm$ $0.4 \mathrm{mU} / 1$ after $60 \mathrm{~min}$ infusion, respectively. The values obtained at 55 and 60 min after the infusion were similar, indicating that a steadystate had been reached.

On a spearate day, glucose $(0.5 \mathrm{~g} / \mathrm{kg}$ body weight as a $50 \mathrm{~g} / \mathrm{d}$ l solution) was infused IV over 2 min in eight normal subjects and in six out of eight of the patients with hyperthyroidism. L-arginine monochloride $(0.2 \mathrm{~g} / \mathrm{kg}$ as a $20 \mathrm{~g} / \mathrm{dl}$ solution) was also infused IV over $2 \mathrm{~min}$ in seven out of eight of the normal subjects and in five out of eight of the patients. Blood samples were taken 5 and $10 \mathrm{~min}$ before and $3,5,10,15,20,30,40,50$ and $60 \mathrm{~min}$ after starting the infusion of glucose or arginine from an indwelling catheter in the other forearm vein through which $0.154 \mathrm{~mol} / 1$ saline was slowly infused.

Blood samples $(1.0 \mathrm{ml})$ were collected in sodium fluoride tubes for plasma glucose determination using the o-toluidine method [8]. Serum insulin was determined by a one-antibody radioimmunoassay system [9].

The glucose disappearance rate $(\mathrm{kg})$ was calculated from minutes $10-60$ by least squares analysis from the slope of the semi-logarithmic plot of plasma glucose concentrations. The lower limit of normal was $1.30 \% / \mathrm{min}[10]$. The insulin delivery rate was estimated by analysing the peripheral serum insulin levels in response to infusion of the glucose or arginine solution, on the basis of the insulin disappearance rate. The theoretical considerations and the computational method have been reported previously $[9,10]$. In brief, the delivery rate was determined by the integral difference of the measured peripheral insulin value and the calculated estimation of the peripheral insulin level as determined from the previously measured insulin value. This estimate was derived from an insulin disappearance rate determined on a different day. The measurement of the disappearance rate of unlabelled insulin may be complicated by the fact that plasma glucose concentration is decreased. The influence of hypoglycaemia on the disappearance rate of insulin, however, is generally considered insignificant [11-14], even if endogenous insulin is unchanged or suppressed. It has been reported that the absolute degradation rate of insulin is proportional to the plasma insulin concentration, i.e. the fractional rate is constant [15]. Although several authors have shown that the irreversible loss rate of insulin is not linearly related to plasma concentration [13-15], the difference is not very large, and it is reasonable to assume that the fractional rate of loss of unlabelled insulin is relatively constant regardless of the plasma concentrations. Therefore, it is reasonable to assume that the calculated rate of insulin removal, following a single dose of insulin, can be applied to the delivery of various amounts of insulin following glucose or arginine infusion. The insulin disappearance rate was obtained from the least squares analysis of a semi-logarithmic plot of total serum insulin level following insulin infusion. The insulin delivery rate can be calculated from peripheral insulin levels by using the disappearance rate of insulin, assuming that the exogenous insulin infused by this route and endogenous insulin are handled in the same way.

The basal delivery rate of insulin was calculated from a fasting level of serum insulin [9]. The apparent distribution space of insulin, halfdisappearance time $t_{1 / 2}$ and metabolic clearance rate have been described elsewhere [9].

All values are expressed as mean \pm SEM. Comparisons between normal subjects and the patients are made using the Student's t-test.

\section{Results}

\section{Insulin disappearance rate}

The mean insulin concentrations following IV bolus injection of insulin in eight normal subjects and eight patients with hyperthyroidism are shown in Figure 1 . At first, the insulin levels fell rapidly in an exponential manner. This was followed by a slower fall of the second component with insulin values which were similar to those found before insulin administration. The first component of fractional insulin removal, estimated from individual insulin levels, was employed in each individual for calculation of the rate constant of insulin disappearance. Then, the rate constants for each individual were applied for calculation of the delivery rate in the same subject.

The mean rate constant for insulin disappearance was $0.2380 \pm 0.0052 \mathrm{U} / \mathrm{min}$ in the control subjects and $0.2147 \pm 0.0111 \mathrm{U} / \mathrm{min}$ in the patients. There was no significant difference in the rate constants between the patients and control subjects. The administration of insulin resulted in a fall in the blood glucose $30 \mathrm{~min}$ later in control subjects to $70 \%(3.6 \pm 0.4 \mathrm{mmol} / 1)$ of the initial value and $20 \mathrm{~min}$ later in the patients to $71 \%$ (3.6 \pm $0.4 \mathrm{mmol} / \mathrm{l}$ ) the initial value. The mean extrapolated insulin level at zero time produced by an IV insulin dose of $4.0 \pm 0.2 \mathrm{U}$ in the normal subjects and $2.1 \pm 0.1 \mathrm{U}$ in the patients was $885 \pm 72$ and $453 \pm 105 \mathrm{mU} / \mathrm{l}$, re- 
Table 2. Amounts of infused insulin, apparent distribution space, half disappearance time and metabolic clearance rate of insulin in normal subjects and hyperthyroid patients

\begin{tabular}{|c|c|c|c|c|c|c|}
\hline & \multirow{2}{*}{$\begin{array}{l}\text { Infused } \\
\text { insulin } \\
\text { (U) }\end{array}$} & \multirow{2}{*}{$\begin{array}{l}\text { Extrapolated } \\
\text { zero time } \\
\text { insulin level } \\
(\mathrm{mU} / 1)\end{array}$} & \multicolumn{2}{|c|}{$\begin{array}{l}\text { Distribution } \\
\text { space }\end{array}$} & \multirow[t]{2}{*}{$\begin{array}{l}t_{1 / 2} \\
(\min )\end{array}$} & \multirow{2}{*}{$\begin{array}{l}\text { Metabolic } \\
\text { clearance rate } \\
\left(\mathrm{ml} \cdot \min ^{-1} \mathrm{~kg}\right. \\
\left.\text { body weight }{ }^{-1}\right)\end{array}$} \\
\hline & & & (l) & $\begin{array}{l}\text { (\% body } \\
\text { weight })\end{array}$ & & \\
\hline Normal subjects $(n=8)$ & $4.0 \pm 0.2$ & $885 \pm 72$ & $4.9 \pm 0.6$ & $7.6 \pm 0.8$ & $2.9 \pm 0.3$ & $17.6 \pm 1.6$ \\
\hline Hyperthyroid patients $(n=8)$ & $2.0 \pm 0.1$ & $453 \pm 105$ & $5.9 \pm 1.0$ & $11.4 \pm 1.9^{\mathrm{a}}$ & $3.3 \pm 0.2$ & $24.4 \pm 4.1$ \\
\hline
\end{tabular}

Results expressed as mean $\pm \mathrm{SEM} ;{ }^{a} p<0.05$ versus normal subjects
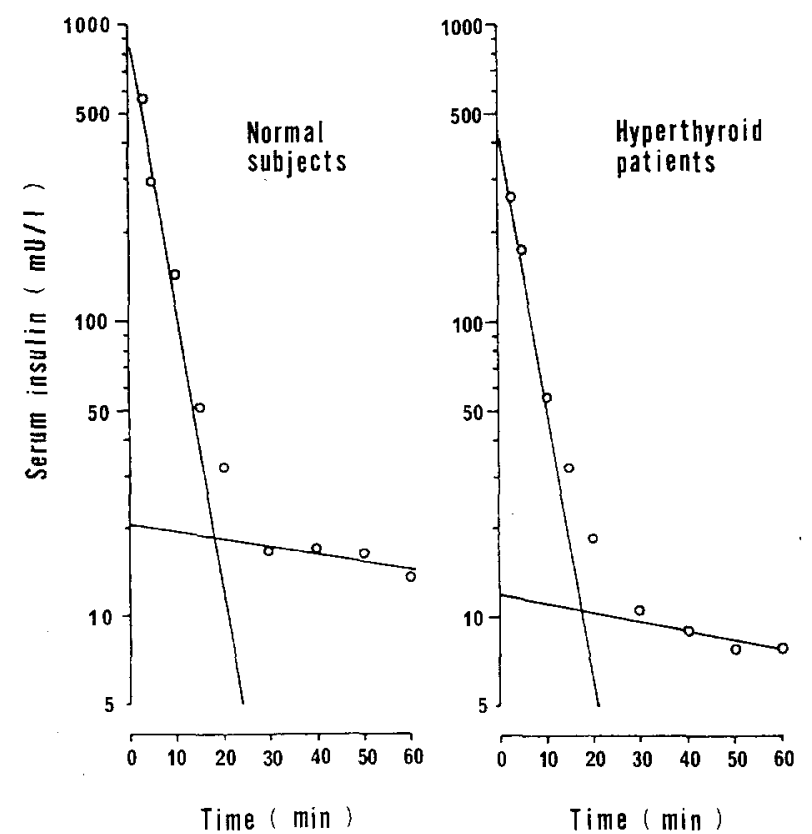

Fig. 1. Semi-logarithmic plot of total mean insulin levels following a monocomponent insulin injection in normal subjects $(n=8)$ and patients with hyperthyroidism $(n=8)$. An infusion of glucose was started $60 \mathrm{~min}$ before the insulin injection and continued throughout the experiment.

spectively. The mean values of distribution space, metabolic clearance rate and $t_{1 / 2}$ are shown in Table 2 . The apparent distribution space $/ \mathrm{kg}$ body weight $(115 \mathrm{ml} /$ $\mathrm{kg}$ ) was larger in the patients than in the controls $(76 \mathrm{ml} /$ $\mathrm{kg}, p<0.05$ ). Although the metabolic clearance rate of insulin was greater in the patients $\left(24.4 \pm 4.1 \mathrm{ml} \mathrm{kg}^{-1}\right.$ $\left.\mathrm{min}^{-1}\right)$ than in the controls $\left(17.6 \pm 1.6 \mathrm{ml} \mathrm{kg}^{-1} \mathrm{~min}^{-1}\right)$, the difference was not statistically significant.

\section{Plasma Glucose and Serum Insulin Responses to Glucose Infusion}

Insulin delivery rate: The plasma glucose concentrations following IV glucose infusion are shown in Figure 2. Four of the six patients and none of normal subjects had $\mathrm{kg}$-values of $<1.30$ (lower limit of normal) [10]. The mean $\mathrm{kg}$-value in the patients $(1.24 \pm 0.11)$ was lower than the controls $(2.11 \pm 0.22 ; p<0.005)$. In the normal subjects, the mean serum insulin level rose from a basal level of $7.2 \pm 1.5 \mathrm{mU} / 1$ to a peak of $122 \pm$

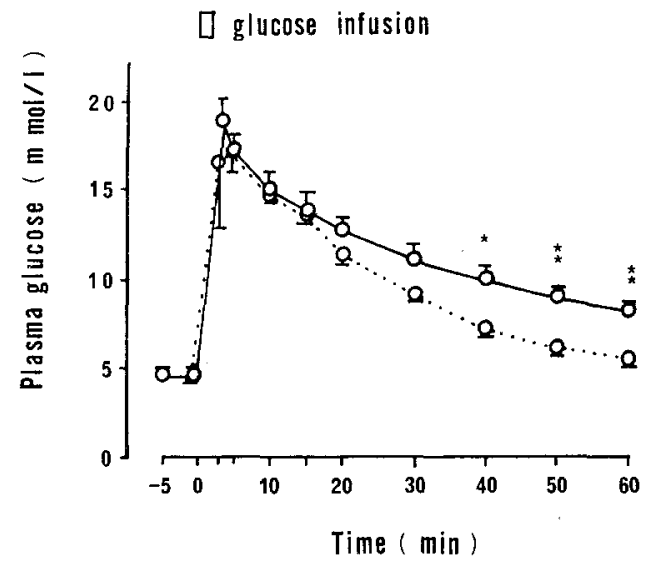

Fig. 2. Mean \pm SEM plasma glucose concentrations following a glucose infusion in normal subjects $\left(\mathrm{O}_{--O} \mathrm{O} n=8\right)$ and patients with hyperthyroidism $(O-O ; n=6) .{ }^{*} p<0.02{ }^{* *} p<0.01$

$16 \mathrm{mU} / \mathrm{l} 5 \mathrm{~min}$ after starting the infusion and decreased to $29 \pm 6 \mathrm{mU} / 1$ at $60 \mathrm{~min}$ (Fig. 3). In the hyperthyroid group, the basal level was $11.5 \pm 3.0 \mathrm{mU} / 1$ and the peak insulin level was $99.5 \pm 6.6 \mathrm{mU} / 13$ min after starting the infusion. The peripheral serum insulin levels were significantly lower in the patients than the controls at 5,10 and $15 \mathrm{~min}(p<0.05$ at 5 and $15 \mathrm{~min}$, and $p<$ 0.02 at $10 \mathrm{~min}$ ). The shaded area between the times of successive sampling was then taken as the quantity of newly secreted insulin on the basis of the rate constant of insulin disappearance (Fig. 3).

Insulin delivery rates calculated from individual insulin levels following glucose infusion are shown in Table 3, using the formula described previously $[11,12]$. The insulin delivery rate after glucose infusion showed a biphasic response in both groups. In the control subjects, the first rapid phase lasted for $10 \mathrm{~min}$. There was a slight but significant increase during the second phase (21-30 min; $p<0.05$ in comparison with the rate during $16-20 \mathrm{~min}$ ). In the patients with hyperthyroidism, the peak during the second phase was observed between 41-50 min, which was delayed compared with the controls (21-30 min), although the characteristics of the first phase were similar. Delivery rates in all segments of both groups were significantly higher than the basal rate $(p<0.01)$. After glucose infusion, the difference of the rates between the controls and patients was significant only during $4-5 \min (p<0.02)$. 

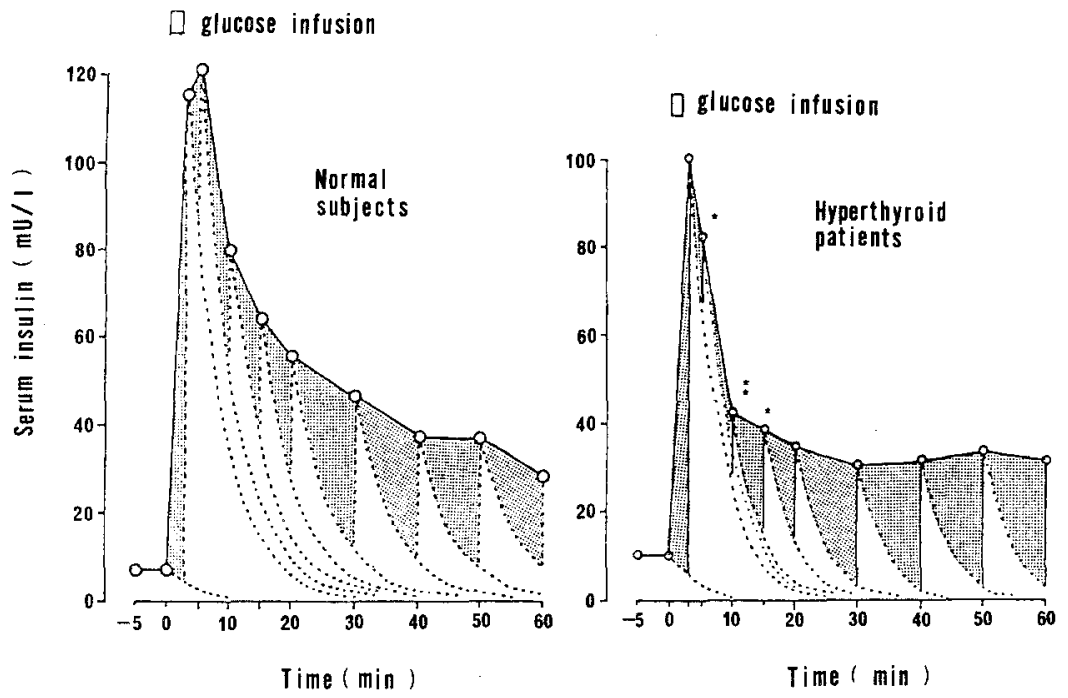

Fig. 3. Mean serum insulin levels following a glucose infusion in normal subjects $(n=8)$ and patients with hyperthyroidism $(n=6)$. Broken lines represent the expected fall in serum insulin concentrations calculated from the insulin disappearance rate. Shaded areas express the quantity of newly secreted insulin. $*_{p}<0.05 \quad * * p<0.02$

Table 3. Calculated insulin delivery rates following a glucose or arginine infusion

\begin{tabular}{|c|c|c|c|c|c|c|c|c|c|c|}
\hline \multirow{3}{*}{ Infusion } & \multicolumn{10}{|c|}{ Insulin delivery $(\mathrm{mU} / \mathrm{min})$} \\
\hline & \multicolumn{10}{|c|}{ Periods after injection (min) } \\
\hline & Basal & $0-3$ & $4-5$ & $6-10$ & $11-15$ & $16-20$ & $21-30$ & $31-40$ & $41-50$ & $51-60$ \\
\hline \multicolumn{11}{|l|}{ Glucose } \\
\hline $\begin{array}{l}\text { Normal subjects } \\
(n=8)\end{array}$ & $8.0 \pm 1.2$ & $272.7 \pm 46.6$ & $128.2 \pm 25.1$ & $133.4 \pm 24.3$ & $121.4 \pm 33.7$ & $107.1 \pm 31.5$ & $144.0 \pm 46.2$ & $104.4 \pm 25.0$ & $121.6 \pm 31.7$ & $80.0 \pm 32.3$ \\
\hline $\begin{array}{l}\text { Hyperthyroid } \\
\text { patients }(n=6)\end{array}$ & $16.2 \pm 6.2$ & $257.4 \pm 69.2$ & $49.8 \pm 14.0^{b}$ & $61.6 \pm 22.9$ & $73.3 \pm 23.4$ & $52.4 \pm 13.3$ & $73.6 \pm 19.7$ & $74.3 \pm 22.4$ & $82.8 \pm 28.8$ & $77.5 \pm 26.0$ \\
\hline Arginine & & & & & & & & & - & \\
\hline $\begin{array}{l}\text { Normal } \\
\text { subjects }(n=7)\end{array}$ & $9.3 \pm 0.8$ & $104.9 \pm 15.6$ & $22.3 \pm 11.2$ & $35.6 \pm 12.6$ & $27.8 \pm 9.5$ & $19.5 \pm 9.1$ & $17.4 \pm 5.4$ & $4.1 \pm 0.5$ & $3.3 \pm 0.3$ & $2.9 \pm 0.1$ \\
\hline $\begin{array}{l}\text { Hyperthyroid } \\
\text { patients }(n=5)\end{array}$ & $18.1 \pm 4.0$ & $53.2 \pm 17.2^{\mathrm{a}}$ & $1.4 \pm 1.4^{\mathrm{a}}$ & $10.0 \pm 5.4$ & $10.2 \pm 4.6$ & $1.0 \pm 0.5$ & $3.0 \pm 1.1^{\mathrm{a}}$ & $2.9 \pm 1.0$ & $3.0 \pm 1.0$ & $2.9 \pm 1.1$ \\
\hline
\end{tabular}

Results expressed as mean $\pm \mathrm{SEM}$

a $p<0.05$ or

${ }^{b} p<0.02$ versus normal control subjects

Amount of insulin delivered (Table 4): There was no significant difference in insulin delivery following glucose infusion in either group during the first $(0-10 \mathrm{~min})$ or second (11-60 min) phase.

\section{Plasma Glucose and Serum Insulin Responses to Arginine Infusion}

Insulin delivery rate: Plasma glucose concentration following IV arginine infusion in seven normal subjects and five patients, who were previously examined for insulin disappearance rate, are shown in Figure 4. Plasma glucose levels in the control subjects rose from a basal level of $4.4 \pm 0.2$ to $5.4 \pm 0.2 \mathrm{mmol} / 1$ at $10 \mathrm{~min}(p<$ 0.01 ). However, in the patients, plasma glucose levels did not rise following a bolus injection of arginine. Thus, the mean peak of glucose levels after arginine infusion was higher in the control subjects than in the hyperthyroid patients $(p<0.05)$. In normal subjects, single bolus of arginine significantly increased the serum insulin levels with a peak of $56.3 \pm 6.6 \mathrm{mU} / \mathrm{l}$
3 min after the start of injection (mean basal level: 9.8 $\pm .1 .2 \mathrm{mU} / 1$ ) (Fig. 5). Serum insulin levels in the patients rose slightly but significantly to the peak level of $29.6 \pm 6.2 \mathrm{mU} / 13 \mathrm{~min}$ following an injection of arginine (mean basal level: $12.0 \pm 1.1 \mathrm{mU} / 1$ ).

Insulin delivery rates calculated from individual insulin levels following arginine infusion are shown in Table 3. The insulin delivery rate showed a monophasic response in both groups. In the control subjects, the rate during the first 3 min after arginine infusion was higher than the basal rate $(p<0.001)$ and 30 min later, the rate was significantly suppressed $(p<0.01)$. In the patients, the delivery rate rose significantly during the first $3 \mathrm{~min}$ after the infusion of arginine $(p<0.01)$. However, during $16-60 \mathrm{~min}$, the rate was lower than the basal rate $(p<0.01)$. Delivery rates during $0-5 \mathrm{~min}$ in hyperthyroid patients were significantly less than in the control subjects $(p<0.05)$.

Amount of insulin delivered (Table 4): Although there was no significant difference in the basal delivery of in- 
Table 4. Amounts of delivered insulin after glucose or arginine infusion

\begin{tabular}{|c|c|c|c|c|}
\hline \multirow{3}{*}{ Infusion } & \multicolumn{4}{|c|}{ Insulin delivery $(\mathrm{U})$} \\
\hline & \multicolumn{3}{|c|}{ Time periods (min) } & \multirow{2}{*}{$\begin{array}{l}\text { Total } \\
(0-60)\end{array}$} \\
\hline & $\begin{array}{l}\text { Basal } \\
(\mathrm{mU} / \mathrm{min})\end{array}$ & $(0-10)$ & $(11-60)$ & \\
\hline Glucose & & ' & & \\
\hline $\begin{array}{l}\text { Normal subjects } \\
(n=8)\end{array}$ & $8.0 \pm 1.3$ & $1.7 \pm 0.3$ & $5.6 \pm 1.6$ & $6.2 \pm 0.7$ \\
\hline \multirow[t]{2}{*}{$\begin{array}{l}\text { Hyperthyroid } \\
\text { patients }(n=6)\end{array}$} & $16.2 \pm 6.2$ & $1.2 \pm 0.3$ & $3.7 \pm 1.1$ & $4.9 \pm 1.3$ \\
\hline & & $(0-10)$ & $(11-30)$ & $(0-30)$ \\
\hline \multicolumn{5}{|l|}{ Arginine } \\
\hline $\begin{array}{l}\text { Normal subjects } \\
(n=7)\end{array}$ & $9.3 \pm 0.8$ & $0.5 \pm 0.1$ & $0.4 \pm 0.1$ & $0.90 \pm 0.2$ \\
\hline $\begin{array}{l}\text { Hyperthyroid } \\
\text { patients }(n=5)\end{array}$ & $18.1 \pm 4.0$ & $0.2 \pm 0.1^{a}$ & $0.1 \pm 0.03$ & $0.28 \pm 0.1^{\mathrm{a}}$ \\
\hline
\end{tabular}

Results expressed as mean \pm SEM

a $p<0.05$ versus normal subjects

Amounts of delivered insulin during 31-60 min after arinine infusion were not calculated because the rates in patients and control subjects were suppressed.

sulin between the control subjects $(9.3 \pm 0.8 \mathrm{mU} / \mathrm{min})$ and the patients $(18.1 \pm 4.0 \mathrm{mU} / \mathrm{min})$, the amounts of the insulin delivered during the first $10 \mathrm{~min}$ following arginine infusion were lower in the hyperthyroid patients than in the control subjects $(p<0.05)$. The total amount of insulin delivered in the patients was significantly decreased $(p<0.05)$.

\section{Discussion}

The rate constants for insulin disappearance in the present study were estimated from the early rapidly declining phase as shown in Figure 1, although studies of the disappearance rate using a single injection of insulin are complicated by the presence of more than one exponential component in the plasma disappearance curve [16]. Thus, the over-all disappearance of the initial phase, evaluated on the basis of clinical study, was used to calculate the post-hepatic insulin delivery rate. To avoid any potential effect of hypoglycaemia on insulin disappearance [11-14], glucose was also administered intravenously. Constantly infused glucose used in our procedure has been reported to reduce markedly hepatic glucose output without a concomitant increase in total glucose utilization $[17,18]$.

In the present study, the fractional removal rate of insulin in the early part of the disappearance curve was not affected by hyperthyroidism. Post-hepatic delivery of insulin following glucose infusion was normal, although peripheral insulin concentrations were significantly decreased at 5, 10 and 15 min after infusion. The fractional removal rate for insulin is directly proportional to the metabolic clearance rate and peripheral

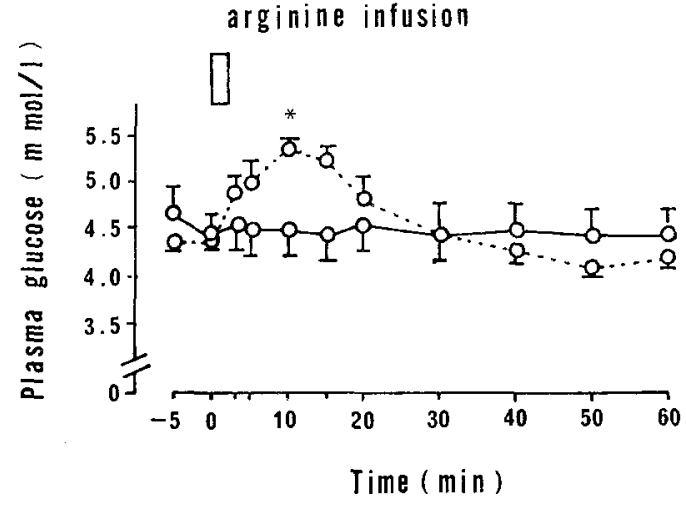

Fig.4. Mean \pm SEM plasma glucose concentrations following an arginine infusion in normal subjects $(\mathrm{O}--\mathrm{O} ; n=7)$ and patients with hyperthyroidism $(O-O ; n=5) . \quad * p<0.05$

\section{$\square$ arginie infusion}

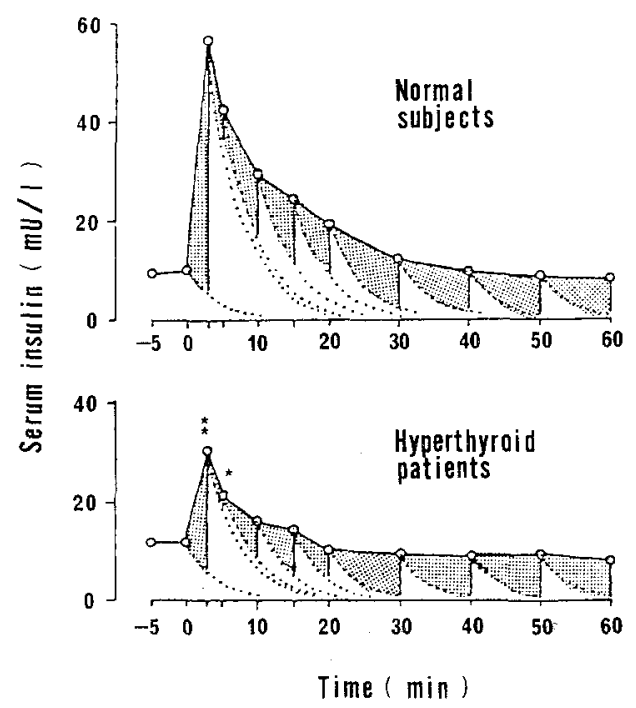

Fig.5. Mean serum insulin levels following an arginine infusion in normal subjects $(n=7)$ and patients with hyperthyroidism $(n=5)$. Broken lines represent the expected fall in serum insulin concentration calculated from the insulin disappearance rate. Shaded areas indicate newly secreted insulin. $* * p<0.02 * p<0.05$

blood flow, whereas it is inversely proportional to the volume of distribution of insulin. Since the distribution space per unit body weight of insulin was larger in the hyperthyroid patients than in normal subjects, it would be expected that the peripheral concentration of insulin might be low. The $\mathrm{kg}$-value can also be interpreted as showing that patients with hyperthyroidism have a larger distribution space for glucose than normal subjects which is in keeping with the observation on insulin secretion.

The present study demonstrates that low kg-values in hyperthyroidism are not due to diminished delivery of insulin into the general circulation. The delivery rate is equivalent to insulin delivered into the systemic circulation rather than insulin secretion and depends, in part, on the extraction rate by the liver. An abnormality in hepatic insulin metabolism in hyperthyroidism cannot 
therefore be excluded. Abnormal metabolism of insulin in the liver, such as a decreased extraction of insulin, might be accompanied by a diminished secretion of insulin, since insulin delivery was not decreased. In addition it has been proposed that pancreatic insulin could be depleted as a result of over-stimulation of insulin release by constantly elevated blood glucose [19]. The changes in glucose handling in hyperthyroid patients may also therefore be partly the result of an inadequate insulin response.

The glycogen content of the liver is markedly diminished in hyperthyroidism and thyroid hormone may primarily decrease the ability of the liver to store glucose as glycogen [20,21]. Decreased glycogen storage in the liver would result in an increased net hepatic output of glucose without an increase in peripheral glucose utilization and bring on impaired glucose tolerance in hyperthyroid patients.

The insulin delivery rate in response to arginine showed a monophasic pattern in both normal subjects and hyperthyroid patients. This result is in good agreement with the data of Pagliara et al. on the perfused rat pancreas [22]. On the other hand, during a prolonged arginine infusion, a biphasic pattern of insulin release has been demonstrated by other investigators $[7,23]$. Since arginine exerts its effect by magnifying the insulin releasing action of glucose and not by an independent mechanism of its own [7, 23], the lack of insulin secretion during the second phase might be due to a low concentration of blood glucose between 11-60 min.

In hyperthyroidism, impaired arginine-induced insulin delivery was accompanied by a failure of blood glucose to rise following the infusion of arginine. The lack of glucose rise may be explained partly by the sluggish rise in plasma glucagon [24] and the impaired response of blood glucose to glucagon injections in hyperthyroidism [19].

It is concluded that the glucose intolerance in hyperthyroidism is primarily caused by the catabolic actions of thyroxine on hepatic carbohydrate metabolism. This results from impaired insulin action rather than from the suppression of insulin secretion by thyroxine.

Acknowledgments. We are grateful to Dr. F. C. Goetz, Department of Medicine, University of Minnesota, Minneapolis, Minnesota, USA for his kind review of this article. Thanks are also due to Morishita Pharmaceuticals, Osaka, for the supply of l-arginine.

\section{References}

1. Hales CN, Hyams DE (1964) Plasma concentrations of glucose, nonesterified fatty acid, and insulin during oral glucose tolerance tests in thyrotoxicosis. Lancet II: 69-71

2. Doar JWH, Stamp TCB, Wynn V, Path FC, Audhya TK (1969) Effects of oral and intravenous glucose loading in thyrotoxicosis. Diabetes 18: 633-639

3. Anderson OO, Friis Th, Ottesen B (1977) Glucose tolerance and insulin secretion in hyperthyroidism. Acta Endocrinol (Copenh) 84: $576-587$

4. Andreani D, Menzinger $G$, Fallucca F, Niberti G, Tamburrano G,
Cassano $C$ (1970) Insulin levels in thyrotoxicosis and primary myxoedema: Response to intravenous glucose and glucagon. Diabetologia $6: 1-7$

5. Renauld A, Andrade LL, Sverdlik RC, Rodriguez RR (1974) Serum insulin response to glucose infusion in hyperthyroid dogs. Horm Metab Res 6: 400-403

6. Elgee NJ, Williams RH (1955) Effects of thyroid function on insulin $\mathrm{I}^{131}$ degradation. Am J Physiol 180: 13-15

7. Imura H, Seino Y, Ikeda M, Taminato T, Miyamoto Y, Goto $Y$ (1976) Impaired plasma insulin response to arginine in hyperthyroidism. Important role of the rise of blood glucose in the second phase of insulin release induced by arginine. Diabetes 25:961-968

8. Hyvärynee A, Nikkila EA (1962) Specific determination of blood glucose with o-toluidine. Clin Chim Acta 7: 140-143

9. Asano T, Sasaki H, Okumura M (1978) Characterisation of the effect of intravenous infusion of glucose and tolbutamide on the insulin delivery rate in man. Diabetologia 15: 159-164

10. Asano T, Sasaki H, Okumura M (1978) Insulin delivery rate in response to glucose infusion in normal and diabetic subjects. Endocrinol Jpn 25:510-527

11. Olefsky JM, Batchelder T, Colome S, Reaven GH (1974) Effect of intravenous glucose infusion on plasma removal rate. Metabolism 23: $543-548$

12. Sönksen PH, Tompkins CV, Srivastava MC, Nabarro JDN (1973) A comparative study on the metabolism of human insulin and porcine proinsulin in man. Clin Sci Mol Med 45: 633-654

13. Frost DP, Stivastava MC, Jones RH, Nabarro JDN, Sönksen PH (1973) The kinetics of insulin metabolism in diabetes mellitus. Postgrad Med J 49: 949-954

14. Turner RC, Grayburn JA, Newman GB, Nabarro JDN (1971) Measurement of the insulin delivery rate in man. $J$ Clin Endocrinol Metab 33: 279-286

15. Sterm MP, Farquhar JW, Silvers A, Reaven GR (1968) Insulin delivery rate into plasma in normal and diabetic subjects. J Clin Invest 47: 1947-1957

16. Sherwin RS, Kramer KJ, Tobin JD, Insel PA, Liljenquist JE, Berman M, Andreas R (1974) A model of the kinetics of insulin in man. J Clin Invest 53: 1481-1492

17. Felig $P$, Wahren $\mathbf{J}$ (1971) Influence of endogenous insulin secretion on splanchnic glucose and aminoacid metabolism in man. $J$ Clin Invest 50: 1702-1711

18. Wahren J, Felig P, Cerasi E, Luft R (1972) Splanchnic and peripheral glucose and aminoacid metabolism in diabetes mellitus. $J$ Clin Invest $51: 1870-1875$

19. Levy LJ, Adesman JJ, Spergel G (1970) Studies on the carbohydrate and lipid metabolism in hyperthyroid disease: Effect of glucagon. J Clin Endocrinol Metab 30: 372-379

20. Marecek RL, Feldman JM (1973) Effect of hyperthyroidism on insulin and glucose dynamics in rabbits. Endocrinology 92 : 1604-1611

21. Hoch EL (1962) Biochemical action of thyroid hormones. Physiol Rev 42: 605-673

22. Pagliara AS, Stillings SN, Hover B, Martin DM, Matschinsky FM (1974) Glucose modulation of aminoacid-induced glucagon and insulin release in the isolated perfused rat pancreas. J Clin Invest 54: 819-832

23. Efendic S, Cerasi E, Luft $\mathrm{R}$ (1971) Role of glucose in arginineinduced insulin release in man. Metabolism 20:568-579

24. Shima K, Sawazaki N, Tanaka R, Morishita S, Tarui S, Nishikawa M (1976) The pancreatic alpha and beta cells response to l-arginine and insulin induced hypoglycemia in hyperthyroidism. Acta Endocrinol (Copenh) 83: 114-122

Received: 2 December 1980

and in revised form: 13 April 1982

T. Asano, M.D.

First Department of Internal Medicine

Fukuoka University Medical School, Nishiku

Nanakuma, Fukuoka City, 814, Japan 